\title{
What determines leverage in selected countries of Cen- tral and Eastern Europe in the automotive industry
}

\author{
Petra Růčková ${ }^{1}$, Nicole Škuláňová ${ }^{2^{*}}$ \\ ${ }^{1,2}$ School of Business Administration, Silesian University, Karvina, Czech Republic
}

\section{Keywords \\ Financial structure Profitability \\ Liquidity \\ Non-debt tax shield \\ Asset structure \\ GDP \\ Inflation}

Interest rate

Received: 15 May 2020

Accepted: 24 July 2020

Published: 20 October 2020

\begin{abstract}
This article aims to analyze the financial structure of companies belonging to the second and third sectors. The issue of funding sources is one of the fundamental decisions of financial managers and has been a much-debated topic in the last century. A number of studies have been written throughout this period, but there is still no consensus, and there is still a need to expand this area with new knowledge for other countries and sectors. The analysis covers medium and large companies engaged in the automotive industry and is located in eleven selected countries, including the Visegrád Group, Austria, Bulgaria, Romania, Slovenia, Germany, Italy, and France. The period under review is between 2010 and 2018. The input data come from the Orbis and World Bank database. The research deals with the impact of profitability, liquidity, asset structure, non-debt tax shield, GDP, inflation, and basic interest rate on the total, long-term, and short-term debt of companies. Panel regression using the GMM method is used to determine the impact of individual factors on debt levels. The main conclusion of the research is that companies in both sectors are mainly affected by the determinants of the external environment, most of all by changes in interest rates. This research builds on existing knowledge and seeks to disseminate it by focusing on specific sectors. From a practical point of view, the results of the research could help companies from the researched sector to optimize their sources of financing with regard to the influence of external determinants, which proved to be more significant.
\end{abstract}

(c) 2020 The Author(s). Published by TAF Publishing.

\section{INTRODUCTION}

For their investment activities, companies need financial resources to which two concepts relate-capital and financial structure. The difference between these two concepts is that the capital structure does not include short-term sources of funding, while the financial structure does. It is the object of this research to examine the impact of selected factors on the financial structure, which comprehensively captures all sources of corporate financing. Efforts to achieve an optimal financial structure are included in the core activities of the financial managers of each business, as the correct setting of this structure affects the profitability and financial risk of the company.

This issue has been a discussed topic since the beginning of the last century, and therefore there are many studies. Unfortunately, individual studies use diverse and incomparable determinants, as we will see below, and as a result, there is still no universal theory of choice of capital structure, as Myers (2001) claims. Therefore, new studies are still emerging with new theories, formulas and factors justifying why companies are using specific sources of funding. However, despite a considerable amount of literature, the authors rely on several basic sources, first of all a 1958 study by Modigliani and Miller, "The Cost of Capital, Corporation Finance and the Theory of Investment", who laid the foundations of modern corporate finance. Second, there are two fundamental theories of capital structure-tradeoff theory and its main representative Brealey, Myers, and Allen (2011) and the pecking order theory and its principal representative, Myers (1984). The first theory argues that companies are looking for a level of debt that balances the tax advantage of another debt with the cost of a potential financial distress. The second theory takes the opinion that equity should be preferred to external capital, while debt

*corresponding author: Nicole Škuláňová

†email: skulanova@opf.slu.cz 
is more appropriate than equity, provided that an external source of financing is needed.

Until the turn of the century, the authors focused mainly on large companies, often listed on the stock exchange. At the same time, the examined countries were chosen from developed countries such as the United States, the United Kingdom, France, Germany, etc. In recent years, the authors have stopped limiting themselves and started to deal with companies regardless of industry, geography or size. These three determinants are the main reason why the results are inconsistent, as a different financial structure is appropriate for each sector. The same applies to the size of company and nationality, as economies differ by the development of financial markets and access to all sources of funding. Most of the theories were based on the Anglo-Saxon environment and therefore their conclusions cannot be fully applied to the Central and Eastern European countries. Also, the number of studies involving these countries is not so high. In their studies, authors such as Hanousek and Shamshur (2011), Hernádi and Ormos (2010), Hernádi and Ormos (2012), Jõeveer (2013), Klapper, Sarria-Allende, and Sulla (2002), Mateev, Poutziouris, and Ivanov (2013)) examined the CEE countries in one common panel, from which country conclusions cannot be drawn. On the other hand, e.g., De Haas and Peeters (2006), Delcoure (2007), Mokhova and Zinecker (2013), Nivorozhkin (2005), Ruckova (2015b), Ruckova (2015a), Ruckova (2017), Weill (2004) have devoted their work to several individual countries in this area, which have brought far more relevant results. Unfortunately, there is a lack of such studies.

The main benefit of this research should be primarily the dissemination of existing knowledge, as the author deals with this field and lacks country and sector studies. It also examines a large sample of companies, a total of 54,927 medium and large companies (all companies from Orbis database) out of eleven selected countries of Central and Eastern Europe. This research should characterize the behavior of companies in the automotive industry; specifically, a manufacturing and wholesale and retail trade and repair of motor vehicles and motorcycles is considered. Companies are analyzed by size, main section and country and tested in individual panels as usually provided.

This paper includes four sections. Section 1 outlines earlier studies involving selected factors and economies. In Section 2 , there are methodology, data and variables described and the industry and researched economies characterized. Section 3 provides with the results of the regression analysis. Section 4 presents the conclusions.

\section{LITERATURE OVERVIEW}

As described above, decisions about the capital structure and its optimization belong to the basic responsibilities of managers. However, this decision is not simple to make because of a number of factors affecting it. These factors are usually divided into in-company and non-company. Both groups are represented in this research. Specifically, the research deals with seven selected determinants-profitability, asset structure, liquidity, non-debt tax shield, company size, macroeconomic development, inflation and interest rates. In the following paragraphs the influence of these determinants on the level of indebtedness discussed in previous researches will be analyzed.

The basic determinant is profitability, which, like most determinants, can have both positive and negative effect. However, it must be said that the negative influence assessed in earlier researches is strongly dominant. On the one hand, if companies' profits grow, they are theoretically further away from bankruptcy than less profitable companies. At the same time, these companies will have lower costs of financial distress. As a result, these companies will be more attractive to creditors willing to provide funding, which will increase debt and have a positive impact. This binding is believed by Brealey et al. (2011) and the trade-off theory. On the other hand, as companies' profits grow, all components grow with profits, and hence retained profits, which can serve as a cheap and highly beneficial source of funding. Given that it is the company's own financial resource, debt level will fall and there will be a negative relation between these variables, mentioned by the pecking order theory and Myers (1984). Negative binding was confirmed in studies of e.g., Cheng and Shiu (2007), De Jong, Kabir, and Nguyen (2008), Gaud, Jani, Hoesli, and Bender (2005), Hernádi and Ormos (2010), Hernádi and Ormos (2012), Mateev et al. (2013), Öztekin (2015), Rajan and Zingales (1995), Ruckova (2015a), (Ruckova, 2017), Wald (1999) involving Slovakia and Poland. If the debt is divided into three forms, which are examined in this research, the resulting impacts are again rather negative, as confirmed by e.g., Delcoure (2007), Handoo and Sharma (2014), Michaelas, Chittenden, and Poutziouris (1999), Mokhova and Zinecker (2013), Nivorozhkin (2005), Song (2005).

The positive effect of liquidity on the debt level can be explained by the fact that the company should possess some amount of highly liquid assets, as these assets can help it to overcome adverse economic developments. Because, as Shleifer and Vishny (1992) claim, if a company gets into trouble, it is usually very difficult to sell illiquid assets. 
Therefore, companies should acquire these assets as little as possible on debt, as Williamson (1988) stated. A reduction of liquidation and financial distress costs becomes the advantage of liquid assets because they can be sold at any time (but of course at a loss). The negative relation between debt and liquidity is due to e.g., the possibility of conflict between managers and investors. Since managers could freely handle assets, they could gradually reduce the company's value and dispose investors by selling liquid assets. This relation is confirmed by e.g., compromise theories of Akdal (2011), Aulova and Hlavsa (2013), Frieder and Martell (2006), Lipson and Mortal (2009), Mateev et al. (2013), Myers and Rajan (1998), Pinkova (2013), Udomsirikul, Jumreornvong, and Jiraporn (2011).

As for tangibility, a positive impact on debt is generally expected in case of overall and long-term debt; in case of short-term debt, this impact should be negative. The nature of the tangible assets, that can usually serve as collateral for long-term loans, can explain such impacts. There is another point of view, e.g., the studies of Stulz and Johnson (1985) and Titman and Wessels (1988) who stated that intangible assets are very difficult to sell in case of necessity (bankruptcy, financial problems) and that in such case, it is usually better to sell the entire company. Whatever the explanation for these impacts is, there are several problems affecting the final assumptions. As the collateral is used for loans, it is clear that in countries whose financial systems are financial market oriented, this relation would not work. Acedo Ramirez and Ruiz Cabestre (2014) and Antoniou, Guney, and Paudyal (2002) showed a positive impact only in bank-oriented countries. Furthermore, it depends on the industry as in some sectors, companies handle a huge amount of inventories due to which collateral cannot be achieved, as reported by Aulova and Hlavsa (2013) and (Ruckova, 2015b). Klapper et al. (2002), Lourenco and Oliveira (2017), Michaelas et al. (1999), Onofrei, Tudose, Durdureanu, and Anton (2015) analyzed another problem namely the size of the company as micro and small companies have less tangible assets than large companies.

As for the non-debt tax shield, the expected impact is often negative as depreciation is a substitute for a tax shield and it should help to reduce debt, too. This impact was revealed by the following authors in their studies - Acedo Ramirez and Ruiz Cabestre (2014), Hernádi and Ormos (2012), Klapper et al. (2002), Michaelas et al. (1999), Song (2005), Wald (1999). In their study, the latter authors also note the possibility of a positive impact, the core of which is justified by the fact that the value of depreciation would be roughly equal to the value of physical assets that can be used as col- lateral, thus increasing debt. Positive impact may also arise from different tax regulations. Positive effects of depreciation were mentioned by e.g., Delcoure (2007), Hernádi and Ormos (2010) and Mokhova and Zinecker (2013).

The remaining three determinants of the capital structure belong to the non-company factors given by the company's external environment. All of them have typical characteristics, namely that in research, first of all, they can also have a positive and negative impact, and unfortunately their coefficients are often statistically insignificant. Therefore, it is important to include these variables to the research as often as possible to get the most statistically significant results. The positive impact of GDP on debt is evident - if the economy thrives and grows, corporate profits are rising, creditors are willing to provide with loans and thus the level of debt could grow. Positive impacts were confirmed by Cekrezi (2013), Mallisa and Kusuma (2017) in Malaysia, Salehi and Manesh (2012). On the other hand, as mentioned in profitability part above, if profits grow, so do retained profits that cause negative impact as found by e.g., Bastos, Nakamura, and Basso (2009), Bokpin (2009), Cheng and Shiu (2007), Hanousek and Shamshur (2011), Mallisa and Kusuma (2017) in Indonesia.

In case of inflation, there is a conflict between the creditor and the debtor as inflation causes existing debt to become lower as inflation increases due to a decline in real interest rates. However, because of the prospect of cheap debt, companies can become more indebted. Unfortunately, the issue of inflation is not as simple. There is another explanation of the negative impact. Obviously, creditors do not want to lose the value of the original debt and may prevent debtors from falling in debt through inflation risk premiums or by connecting the interest rates with inflation. In this case, the debt would become more expensive and companies should avoid it. These measures are mainly applied to short-term debt. Negative binding was found by e.g., Camara (2012), Cekrezi (2013), Cheng and Shiu (2007), Hatzinikolaou, Katsimbris, and Noulas (2002), Jõeveer (2013), and Öztekin (2015). Positive impacts were confirmed by Bokpin (2009), De Haas and Peeters (2006), Khemiri and Noubbigh (2018), Salehi and Manesh (2012) and Sett and Sarkhel (2010). If companies need sources to finance their debts, they obviously would want to do so at the lowest cost, i.e. they would take interest rates into account. When analyzing this determinant, it is necessary to divide the economies according to whether they are already developed or they just go through development. Based on such division, the resulting impacts are expected. The reason is that in developed economies, interest rates are usually low (maximum 
single-digit) and in developing economies, rates are higher (double-digit) as stated by e.g., Yinusa, Alimi, and Ilo (2016). Therefore, short-term loans dominate in these countries. Another difference is in a quality of the institutional, legal and regulatory environment. This implies that for developed economies, a positive impact is expected and for developing economies, a negative relation with debt levels is expected. Unfortunately, in spite of these initial expectations, the results of the research are often quite the opposite. For example, Khemiri and Noubbigh (2018) dealt with sub-Saharan African countries, which are certainly not developed countries, yet interest rates have a positive impact on debt levels. However, the authors explained this unexpected fact by choosing a nominal rate that reflected the effect of inflation, which was also found to have a positive impact. Similarly, Cekrezi (2013) focused on Albanian companies, where she revealed a positive impact. Hatzinikolaou et al. (2002) dealt with the United States, where a negative impact was found out.

\section{DATA AND METHODOLOGY}

Companies of the so-called extended Visegrád Group involving the Czech Republic (CZ), Slovakia (SK), Poland (PL), Hungary (HU), Austria (AT), Slovenia (SI), Romania (RO), Bulgaria (BG), Germany (DE), Italy (IT) and France (FR) become the subject of the research. This research compares the countries of the extended Visegrád Group ${ }^{1}$ and the major producers in Europe. The whole group of countries was chosen to broaden knowledge mainly to Central and Eastern Europe. The examined companies are listed in the Orbis database and belong to the sector C-Manufacturing, division 29-Manufacturing of motor vehicles, trailers and semitrailers and to the sector G-Wholesale and retail trade, repair of motor vehicles and motorcycles (according to the NACE statistical classification).

As for the period 2010-2018, a total of 54,927 companies, of which 3,201 are medium-sized in manufacturing and 40,436 medium-sized in wholesale and retail, and 2,218 large companies in manufacturing and 7,698 large companies in wholesale and retail was considered. These enterprises were found regardless of what they were specifically involved in and to which sub-sector they belong. The research wants to compare the whole industry regardless of its individual parts. The data needed for research comes from the Orbis and World Bank databases, which include long enough time periods to elaborate a quality research.
The aim of this research is to determine the influence of selected factors on the financial structure of the companies of eleven selected economies belonging to manufacturing and wholesale and retail trade of motor vehicles. Based on a review of earlier studies mentioned above, the following five research questions were formulated:

1. Is there a negative impact of profitability, liquidity, nondebt tax shield and inflation and positive impact of asset structure, GDP growth on total debt?

2. Is there a negative impact of profitability, liquidity, nondebt tax shield and inflation and positive impact of asset structure, GDP growth on long-term debt?

3. Is there a negative impact of profitability, liquidity, asset structure, non-debt tax shield and GDP growth and positive impact of inflation on short-term debt?

4. Is there a positive impact of the base interest rate on indebtedness of developed countries (CZ, SK, SI, DE, AT, IT, FR)?

5. Is there a positive impact of the base interest rate on indebtedness of developing countries (RO, $\mathrm{HU}, \mathrm{BG}, \mathrm{PL}^{2}$ )?

\section{Variables}

The dependent variable in the regression equation is represented by indebtedness, which has three forms: 1) debtequity ratio for total debt (DER) $=$ share of total liabilities to equity, 2) debt-equity ratio for long-term debt (DER_L) = ratio of long-term debt to equity 3 ) debt-equity ratio for short-term debt (DER_S) = share of short-term liabilities to equity.

The regression model analyses the effect of seven independent variables on the dependent variable. Specifically, it is the ratio of pre-tax profit and interest expense to total assets (ROA), the company's quick liquidity as a ratio of current assets excluding inventories and short-term liabilities (L2), the share of fixed assets to total assets (SA), the ratio of depreciation to total assets (DEPR), company's size, GDP growth rate, inflation rate (INF) and base rate (IR).

\section{METHODOLOGY}

A panel regression will be used to analyze the impact of factors on the financial structure, whose panels will consist of annual financial data. Unfortunately, simple panel regression is not suitable for shorter time periods and the need for stationary data (Prucha, 2014). Therefore, a twostage system Generalized Method of Moments (GMM) will be used which is also suitable for shorter time periods, nonstationary data can be used (ideal for macroeconomic fac-

$1 \quad$ Extended Visegrád Group-it is V4 and Austria, Slovenia, Romania and Bulgaria. These four countries were chosen as their representatives often attend V4 meetings and there is cooperation between these economies.

2 According to International Monetary Fund-World Economic Outlook from April 2019 
tors); there is an error correlation check and there may not be a strict exogenous variable in the model Arellano and Bond (1991). However, the chosen model also has its drawbacks represented by the absence of a heteroscedasticity test and autocorrelation of variables. For this reason, it is necessary to perform a robustness test so that the result- ing model has a certain informative value. In this research, it will be a Sargan test used claiming that if its values are greater than 0.05 , the model can be considered robust.

Relationships between variables will be investigated according to the following equation:

$$
\begin{array}{r}
D E R_{i t}=\alpha_{0}+\beta_{1} * D E R_{i t-1}+\beta_{2} * R O A_{i t}+\beta_{3} * S A_{i t}+\beta_{4} * L 2_{i t}+\beta_{5} * D E P R_{i t}+\beta_{6} \\
* G D P_{i t}+\beta_{7} * I N F_{i t}+\beta_{8} * I R_{i t}+\varepsilon_{i t}
\end{array}
$$

where the endogenous variable is represented by the debtequity ratio of the i-th number of companies in a given industry in a given country during period $t$, this variable being in triplicate for total, long-term and short-term debt. Furthermore, in the equation, the individual factors-ROA, SA, L2, DEPR, GDP, INF, IR are characterized above. The symbols $\alpha$ and $\varepsilon$ denote a constant and a random component of the model that represents all other influences that may affect the financial structure and cannot be overlooked. Last but not least, the equation also contains the lagged value of the dependent variable, which allows modeling of the partial adaptation mechanism in a dynamic model. Since the data used have an annual frequency, the lag will also be one year.

\section{Characterization of Automotive Industry}

This research focuses on companies of two industries related to the automotive industry. The production and sale of vehicles are concerned. From an economic point of view, these are cyclical sectors whose performance will always depend on the level of consumer confidence; in short, when the economy is going well, the industry is going to prosper, when the economy is going to fall, the sector is going to go down as well.

As far as the production of vehicles is concerned, this sector is very dynamic, as the development of today's cars dates back to 1885 . It is a relatively young sector but rapidly changing. Today, the industry faces unprecedented changes in history. These changes include digitization, robotization, customization, alternative drives, vehicle sharing, autonomous technology etc. With these innovations, carmakers must fight for their future existence and are not replaced by new companies. All these changes are required to be made. They have already required huge funding and human capital. This research focuses on a European environment, in which automotive leaders come predominantly from France (Renault, Peugeot, Citroën), Italy (Ferrari, Lamborghini, Fiat, Lancia, Piaggio, Maserati, Iveco, Alfa Romeo) and Germany (Opel, Audi, BMW, Porsche, Smart, Volkswagen, Daimler AG, Multicar). The development of production is presented in Table 1.

\begin{tabular}{|c|c|c|c|c|c|c|c|c|c|}
\hline \multicolumn{10}{|c|}{ Production of Vehicles } \\
\hline & 2010 & 2011 & 2012 & 2013 & 2014 & 2015 & 2016 & 2017 & 2018 \\
\hline $\mathrm{CZ}$ & 1076384 & 1199845 & 1178995 & 1132931 & 1251220 & 1303603 & 1349896 & 1419993 & 1345041 \\
\hline SK & 561933 & 639763 & 926555 & 975000 & 971160 & 1000001 & 1040000 & 1001520 & 1090000 \\
\hline PL & 869474 & 838133 & 654756 & 590159 & 593504 & 660603 & 681837 & 689729 & 659646 \\
\hline $\mathrm{HU}$ & 211461 & 213531 & 217840 & 321287 & 436469 & 495370 & 472000 & 505400 & 430988 \\
\hline AT & 104997 & 152505 & 247204 & 166428 & 272000 & 125500 & 108000 & 99880 & 164900 \\
\hline SI & 211340 & 174119 & 130949 & 93734 & 118591 & 133092 & 133702 & 189852 & 209378 \\
\hline RO & 350912 & 335232 & 337765 & 410997 & 391434 & 387177 & 359306 & 359250 & 476769 \\
\hline $\mathrm{DE}$ & 5905985 & 6146948 & 5649260 & 5718222 & 5907548 & 6033164 & 6062562 & 5645581 & 5120409 \\
\hline IT & 838186 & 790348 & 671768 & 658206 & 697864 & 1014223 & 1103516 & 1142210 & 1060068 \\
\hline FR & 2229421 & 2242928 & 1967765 & 1740220 & 1821464 & 1970000 & 2082000 & 2227000 & 2270000 \\
\hline$\Sigma$ & 10130672 & 10490424 & 10015092 & 10066964 & 10639790 & 11152733 & 11310819 & 11053415 & 10557199 \\
\hline World & 77583519 & 79880920 & 84238171 & 87595998 & 89776465 & 90780583 & 94976569 & 97302534 & 95634593 \\
\hline
\end{tabular}

TABLE 1. Number of vehicles produced (passengers' cars + commercial vehicles, in thousands)

Source: OICA (2020a) Production statistics 
The other side of the coin, the demand for vehicles and hence their sale is. Its development in given countries and in the world can be seen in Table 2 .

There are several common characteristics regarding the development of vehicle production and sales. Specifically, the sale decreased in 2012 and 2013. In these years, the entire Europe as well as the world suffered a decrease in demand and a slowdown in production activity. The whole Euro zone slowed down and in several countries out of the eleven economies, recessions or some crises were taking place e.g., in the Czech Republic due to a decline in domestic consumption and investment, a banking crisis escalating in Slovenia, in Slovakia, there is also a decline in demand due to the introduction of policies to reduce government debt and unemployment. Last but not least, the European debt crisis started in Europe. Furthermore, Table 2 shows a decline in sales in 2010, which was caused by the rollout of the financial crisis in 2008/2009.

TABLE 2. Number of vehicles sold (passengers' cars + commercial vehicles, in thousands)

\begin{tabular}{|c|c|c|c|c|c|c|c|c|c|}
\hline \multicolumn{10}{|c|}{ Sales of Vehicles } \\
\hline & 2009 & 2010 & 2011 & 2012 & 2013 & 2014 & 2015 & 2016 & 2017 \\
\hline $\mathrm{CZ}$ & 186790 & 186648 & 194945 & 193795 & 185939 & 215594 & 260070 & 291008 & 301805 \\
\hline SK & 92761 & 73820 & 77904 & 78189 & 75204 & 81960 & 90091 & 100600 & 103689 \\
\hline PL & 322341 & 366577 & 338781 & 329799 & 353197 & 392476 & 432439 & 504550 & 577297 \\
\hline $\mathrm{HU}$ & 70808 & 55221 & 60993 & 68168 & 72975 & 88719 & 100933 & 123807 & 136465 \\
\hline AT & 350429 & 362564 & 396655 & 374829 & 357892 & 342215 & 349597 & 374545 & 402924 \\
\hline SI & 63286 & 66871 & 67451 & 57042 & 59782 & 61934 & 68973 & 76213 & 71264 \\
\hline RO & 133561 & 104090 & 95508 & 80723 & 71016 & 100336 & 120591 & 142020 & 121981 \\
\hline BG & 26813 & 20082 & 23529 & 22770 & 22966 & 24331 & 28053 & 31260 & 38394 \\
\hline DE & 4049353 & 3198416 & 3508454 & 3394002 & 3257718 & 3356718 & 3539825 & 3708867 & 3810408 \\
\hline IT & 2357443 & 2164153 & 1942949 & 1545764 & 1420814 & 1493008 & 1726079 & 2050292 & 2191760 \\
\hline FR & 2718599 & 2708884 & 2687052 & 2331731 & 2207373 & 2210927 & 2345092 & 2478472 & 2549402 \\
\hline$\Sigma$ & 7653585 & 6598442 & 6707169 & 6145081 & 5877503 & 6157291 & 6716651 & 7403162 & 7755987 \\
\hline World & 65568829 & 74971523 & 78170420 & 82129138 & 85606136 & 88338098 & 89684608 & 93856387 & 95660606 \\
\hline
\end{tabular}

Source: OICA (2020b) Sales statistics

In Table 3, we can see the distribution of companies in the industries. The table shows the dominance of German, Italian and French companies in the examined sample in the sectors concerned. As mentioned above, these economies are European leaders in the production and sales of cars.

TABLE 3. The distribution of companies in the industries by country

\begin{tabular}{llllllllllll}
\hline & CZ & SK & PL & HU & AT & SI & RO & BG & DE & IT & FR \\
\hline Medium-sized companies & & & & & & & & & & & \\
\hline Manufacture & 222 & 93 & 402 & 116 & 70 & 37 & 145 & 37 & 844 & 774 & 454 \\
Wholesale and retail trade & 2301 & 760 & 3063 & 1372 & 1499 & 442 & 1358 & 704 & 10027 & 9258 & 7660 \\
\hline Large and very large companies & & & & & & & & & & \\
\hline Manufacture & 253 & 116 & 268 & 125 & 64 & 28 & 125 & 23 & 449 & 383 & 384 \\
Wholesale and retail trade & 339 & 143 & 639 & 207 & 201 & 87 & 133 & 87 & 1520 & 1776 & 2550 \\
\hline \hline
\end{tabular}

Source: Author's calculations based on data from Orbis database

\section{Characterization of Economy Development in Consid- ered Countries}

Before presenting the results, it is important to outline the economic development within the referenced period of 2010 to 2018 in selected economies. During that time, several common events took place affecting almost all economies, the financial crisis of 2008/2009, which had impacted countries for the next few years, and the European debt crisis, which had started at the end of 2009 and continued in 2010. Also in 2013, the worldwide economy slowed down. Each country responded differently to these key economic events. In addition, some countries had internal problems as well.

The following paragraphs briefly summarize the basic characteristics of economic development in selected economies. A more detailed analysis will be presented together with the results because unless the resulting coefficients are statistically significant, it is irrelevant to analyse the economic development of the country.

The economies of Poland and Bulgaria were practically not 
affected by events mentioned above. Poland did not go through a decline in GDP growth considering given periods. This situation was due to the fact that the Polish economy is quite large and closed and, in addition, in 2012, Poland was one of the countries hosting the European Football Championship and huge investments were made. The only economic "problem" was deflation in 2014-2016 due to cheaper food due to a ban on exports of certain types of food to Russia.

While Bulgaria's GDP declined in 2009, unemployment and the government deficit increased, all indicators were flattened and of normal limits over the period 2010-2018. The Czech Republic and Slovakia were also not strongly affected by the events. In case of the Czech economy, although GDP declines are observable, however, they had no enormous impact on the economy. Unfortunately, the inflation target was not met in the period under review so the Czech National Bank introduced exchange rate interventions for the period 2013-2017.

A similar development took place in Slovakia. The slight impact of the financial crisis was caused by the insignificance of the Slovak Stock Exchange and by the fixation of the Slovak crown against the euro, which entered the Euro zone in 2009.

As for Germany, Austria and France, those were hit harder by crises, but economies recovered due to various government measures and did not show major fluctuations during the reporting period. In Germany, there was a need to rescue banks and guarantee deposits. Deposit guarantees were also applied in Austria and France. As a result of these measures, the government deficit and government debt and unemployment increased. By 2018, these economies had stabilized.

The last group of countries considered, Hungary, Slovenia, Romania and Italy are. Unfortunately, these countries have undergone very unfavourable development during the examined period, mainly due to the financial crisis. The Romanian government was forced to apply for a loan aimed at strengthening foreign exchange reserves and kicking up the credit market. The loan helped and the Romanian economy recovered.

The Hungarian government also had to apply for a loan due to the government's poor management and the weakening forint due to the financial crisis. Again, the loan was successful and the economy stabilized.

Slovenia has suffered the same mistake as the United States
- the real estate bubbled and its financing through bank loans crashed. After the financial crisis, the Slovenian economy went into a banking crisis, which was mainly caused by banks owned by the state. However, despite these considerable problems, the Slovenian government has resolved everything on its own and stabilized the economy.

Italy is the last country, which has not yet recovered from the financial crisis. As a result, it is also often mentioned in the context of the debt crisis, as the government deficit exceeds $130 \%$ of GDP. In addition to these crises, Italy was facing a banking crisis and was not far from the collapse of the entire banking system. There is also still a high unemployment rate in the country.

\section{Dependent Variable Analysis}

Before the results of the regression analysis will be presented, it would be good to analyse a dependent variable, which is indebtedness-namely debt-equity ratio in three forms - total, long-term and short-term. In Table 4, we can see the average debt-equity ratio for total debt by country, company size and sector. At first sight, it is clear that on average companies are highly indebted, as in almost all countries the indicator is above 1 (except for Czech and Romanian medium and large Hungarian manufacturing companies). The low indebtedness of the three countries is given by the ratio total liabilities/equity. The distribution of these items can be seen in the graphs in Appendix 2. The graphs clearly show that among the Czech Republic medium-sized companies, $53 \%$ of them prefer equity, as for Romanian companies, even $90 \%$ and as for Hungarian large companies, $71 \%$ of them prefer equity. In some countries, the use of debt or equity is almost balanced, nevertheless, debt exceeds 1 and thus liabilities far exceed equity. The ratio of debt/equity is as follows: medium-sized manufacturing companies of CZ 47:53, of HU 51:49, of AT 56:44, of FR 54:46; medium-sized wholesale and retail companies of CZ 57:43, of HU 55:45, of SI and of BG 59:41; large manufacturing companies of CZ 52:48, of PL 52:48, of AT and of SI 58:42; large wholesale and retail companies of BG 58:48. Appendix 1 shows the composition of total liabilities. The graphs show that in almost all countries, companies prefer short-term liabilities. The opposite is true in Austria, where companies use rather long-term debt sources of financing. Medium-sized companies in both sectors even 97\%; 79\% for large companies and $88 \%$ for large wholesale and retail) companies. Another country where the shift towards short-term liabilities is not entirely clear, Germany is. 
TABLE 4. Average debt-equity ratio for selected countries during the period 2010-2018

\begin{tabular}{|c|c|c|c|c|c|c|c|c|c|c|c|}
\hline & $\mathbf{C Z}$ & SK & PL & $\mathrm{HU}$ & AT & SI & RO & BG & DE & IT & FR \\
\hline Medium-sized manufacture companies & 0,91 & 7,96 & 4,28 & 1,05 & 1,30 & 2,55 & 0,09 & 21,08 & 1,59 & 2,63 & 1,20 \\
\hline Medium-sized wholesale and retail trade companies & 1,31 & 2,58 & 1,43 & 1,25 & 1,97 & 1,48 & 1,55 & 1,49 & 2,74 & 2,94 & 1,51 \\
\hline Large manufacture companies & 1,08 & 1,50 & 1,11 & 0,48 & 1,42 & 1,40 & 1,52 & 4,33 & 2,83 & 2,38 & 2,95 \\
\hline Large wholesale and retail trade companies & 1,81 & 2,31 & 2,42 & 2,25 & 2,69 & 1,94 & 2,15 & 1,36 & 3,20 & 2,80 & 3,56 \\
\hline
\end{tabular}

Source: Author's calculations based on data from Orbis database

\section{RESULTS AND DISCUSSION}

Tables 5, 6, 7 and 8 show the results of panel regression by size and industry. Eleven economies were analyzed. At first sight, it is apparent that none of the tables shows all eleven economies by individual forms of debt. The reason for not including some economies, the failure to meet the basic GMM test and the Sargan robustness test is. In the following tables, the last column shows $J$-stat. results. These results must exceed 0.05 to be considered robust and trusted. Economies missing in the results had values below 0.05 , very often equal to zero, and therefore their results have no meaningful value.

Before analyzing the individual result coefficients for selected determinants, the tables include a variable being an automatic part of the GMM model - the lagged debt value. In total, there were ninety-one statistically significant coefficients, of which fifty-one were positive and forty were negative. Thus, manufacturing companies have a positive impact on past debt. In case of sellers, the impact depends on the company size, where medium-sized companies dominate by negative impact, while large companies dominate by positive impacts. Unfortunately, the coefficients are very low, in the order of tenths, hundredths, thousandths, and therefore the impact of past debt on future debt is not significant. The only exception the Czech medium-sized manufacturing companies are as for total and short-term debt. Their coefficients are 3.89 and 10.16. A positive impact indicates that if companies used debt financing in the past, they would continue to use it in the future. In case of the Czech Republic, the increase will be quite large especially in case of short-term debt.

One of the determinants, the company's liquidity is which can also be summarized for all companies at once. There are thirty-four statistically significant coefficients, most of which are positive. It is necessary to say that in large companies, the negative impact prevails and in the medium-sized companies, the positive impact prevails. Almost all coefficients have the same characteristics as the lagged debt value has and that the coefficient values are again in tenths, hundredths and thousandths. Only one coefficient - for large wholesale and retail Bulgarian companies as for short-term debt-exceeds these very low values. The coefficient is equal to 1.18 , which is also not much, but there is a certain predicative value here. The positive prevailing impact means that companies should handle a certain amount of highly liquidation assets to help them overcome a potential economic crisis. These assets should be purchased on debt increasing thus its value. The detailed structure of assets would be appropriate to look at and thus confirm this theory if the coefficients were at least in the order of tens or hundreds.

The Table 5 presents the relation between profitability and debt. A negative impact on all forms of debt was predicted. This prediction came up by Czech companies as for total and long-term debt, Slovenian and French companies as for long-term and short-term debt and German companies as it comes to short-term debt. All these economies went through the economic growth within the most part of the period under review, which is usually connected with the growth of company profits. Companies of the mentioned economies probably preferred to use their profits (specifically retained profits) to finance corporate investments and the debt level thus decreased. These companies are theoretically advantaged over companies with a positive impact as companies will be better able to cope with any economic crisis due to lower debt. Companies with a positive relation between variables with profit growth use more debt financing. The profit growth is the aspect giving such opportunity to the companies and makes the company looking better in the eyes of creditors.

The impact of asset structure on the debt level was expected to be positive as it comes to the total and long-term debt and a negative on short-term debt. These relations were confirmed by Polish and Bulgarian companies as for total debt, by Czech, Italian and French companies as it comes to long-term debt and by Czech and German companies as for short-term debt. A positive impact means that companies are likely to use tangible assets as collateral when deciding on a debt financing. In the case of Poland, Bulgaria, the Czech Republic, Italy and France, these relations are justified because they are banking-oriented financial systems. Conversely, the expected negative impact on shortterm debt is obvious, since tangible assets are not usually used as collateral for short-term loans. As far as the results 
are concerned, it is much more interesting that prediction of positive relation with total indebtedness was not fulfilled as it comes to Slovenian and French companies and as for Romanian companies, long-term indebtedness is concerned. It could be expected that, as it is manufacturing industry, companies may handle a large amount of inventories that would just change the impact to negative. Unfortunately, in a detailed analysis of assets, it has been found out that when considered all assets, more than $70 \%$ of them were tangible ones. As Romanian companies are considered, it is $99 \%$ of tangible assets.

The non-debt tax shield was expected to be negative for all forms of debt. With the exception of three cases, this impact has been confirmed and the idea that a non-debt tax shield substitutes the tax shield and reduces the level of debt can be confirmed. The positive impacts in Czech, Romanian and Slovenian companies are probably explained by differences in tax legislation. As it comes to the second idea on the equality of tangible assets and depreciation values has not been confirmed.

Further, external determinants of the financial structure and the rate of GDP growth are going to be discussed. The GDP growth was expected to have a positive impact on total and long-term debt and a negative impact on short-term debt. For the inflation rate, the expected impacts were exactly the opposite. In case of the basic interest rate, it depended on the division of countries according to the development of their economy proved by IMF. For developed economies (CZ, SK, SI, DE, FR, IT), a positive impact should be confirmed, for developing economies (PL, HU, BG, RO) a negative impact was expected.

As far as GDP is concerned, the findings of negative impacts on total debt in the Czech and Bulgarian companies and on long-term debt in Bulgarian and German companies means that companies were less indebted during e.g., economic expansion. This can be explained by increasing profitability and profits, which can also serve as cheap source of funding. To all three economies, this explanation can be applied as GDP of economies grew within most of the examined period and, in aggregate, this growth outweighed negative effects of the 2009 financial crisis or the smaller economic recessions e.g. in the Czech Republic in 2012/2013.

Considering Bulgarian and Slovenian companies, the positive effect of inflation is unusual as the average inflation rate over the whole reviewed period was $1 \%$ and therefore, there is no advantage of cheaper debt, whether existing or newly incurred ones. Almost all countries with statistically significant coefficients had low inflation rates on average between 2010 and 2018. Romania represents one exception. It had an average inflation rate of around 3\%, and the negative relations between short-term and long-term debt are thus justified.

The variable of interest rate is the last aspect to discuss. It is important to explain the unexpected impacts. The positive impact in case of Poland is justified by the fact that, firstly, the economic development was very good and companies could borrow theoretically even at higher interest rates. On the other hand, interest rate cuts started in 2012, which could have led the company to become more indebted. The positive impact in Romania can be explained by a loan in the context of the economic crisis. This loan was supposed to kick in the credit market, while interest rates were lowered. Negative impacts in Slovak and German companies could occur due to good economic development and no need for indebtedness even at times of very low interest rates within Euro zone countries.

TABLE 5. GMM results for medium-sized manufacturing companies

\begin{tabular}{|c|c|c|c|c|c|c|c|c|c|}
\hline & DER(-1) & ROA & L2 & SA & DEPR & GDP & INF & IR & $J$-stat \\
\hline \multicolumn{10}{|c|}{ Medium-sized companies } \\
\hline \multicolumn{10}{|c|}{ Total debt } \\
\hline $\mathrm{CZ}$ & $3.89^{\mathrm{a}}$ & $-12.17^{a}$ & & & & $-281.84^{a}$ & & $463.81^{c}$ & 0.19 \\
\hline PL & $0.03^{\mathrm{a}}$ & & $0.08^{\mathrm{a}}$ & $35.89^{\mathrm{a}}$ & $-25.08^{b}$ & $238.18^{\mathrm{a}}$ & & $325.39^{\mathrm{a}}$ & 0.26 \\
\hline SI & $0.04^{\mathrm{a}}$ & $-17.62^{\mathrm{a}}$ & & $-19.72^{\mathrm{a}}$ & & & $413.07^{\mathrm{a}}$ & & 0.23 \\
\hline BG & $0.21^{\mathrm{a}}$ & & $0.05^{\mathrm{a}}$ & $3.76^{\mathrm{a}}$ & $-8.75^{\mathrm{a}}$ & $-31.72^{a}$ & & & 0.39 \\
\hline IT & $0.06^{\mathrm{a}}$ & $7.03^{c}$ & $0.01^{\mathrm{a}}$ & & $-14.97^{\mathrm{a}}$ & & $-99.01^{\mathrm{a}}$ & $229.44^{\mathrm{a}}$ & 0.16 \\
\hline FR & $0.001^{\mathrm{a}}$ & & $0.00^{\mathrm{c}}$ & $-17.29^{b}$ & $-64.76^{\mathrm{a}}$ & & $-61.50^{\mathrm{a}}$ & & 0.08 \\
\hline \multicolumn{10}{|c|}{ Long-term debt } \\
\hline $\mathrm{CZ}$ & $0.02^{\mathrm{a}}$ & $-1.69^{\mathrm{a}}$ & & $1.50^{\mathrm{a}}$ & $2.32^{\mathrm{b}}$ & & $-138.14^{\mathrm{a}}$ & & 0.09 \\
\hline BG & $0.56^{\mathrm{a}}$ & $0.61^{\mathrm{a}}$ & & & $-4.95^{\mathrm{a}}$ & $-7.12^{\mathrm{a}}$ & $3.96^{\mathrm{a}}$ & & 0.22 \\
\hline
\end{tabular}

Source: author's calculations based on data from Orbis databases Symbols ${ }^{\mathrm{a}}$, ${ }^{\mathrm{b}}$, or ${ }^{\mathrm{c}}$ indicate significance at $1 \%, 5 \%$, or $10 \%$. 
TABLE 5. Continue...

\begin{tabular}{|c|c|c|c|c|c|c|c|c|c|}
\hline & $\operatorname{DER}(-1)$ & ROA & L2 & SA & DEPR & GDP & INF & IR & $J$-stat \\
\hline RO & $-0.05^{a}$ & & $0.03^{\mathrm{a}}$ & $-3.11^{\mathrm{a}}$ & $16.54^{\mathrm{a}}$ & $106.67^{\mathrm{a}}$ & $-150.53^{a}$ & $249.10^{a}$ & 0.38 \\
\hline $\mathrm{DE}$ & $-0.12^{\mathrm{a}}$ & $52.90^{\mathrm{a}}$ & $0.01^{\mathrm{a}}$ & & & $-128.83^{a}$ & & & 0.48 \\
\hline IT & $0.25^{\mathrm{a}}$ & $1.67^{\mathrm{c}}$ & & $3.52^{\mathrm{a}}$ & & & $-27.31^{\mathrm{a}}$ & $137.71^{\mathrm{b}}$ & 0.17 \\
\hline FR & $-0.03^{\mathrm{a}}$ & $-1.57^{\mathrm{a}}$ & & $5.95^{\mathrm{a}}$ & $-12.73^{a}$ & $25.74^{\mathrm{a}}$ & & $61.91^{\mathrm{a}}$ & 0.06 \\
\hline \multicolumn{10}{|c|}{ Short-term debt } \\
\hline $\mathrm{CZ}$ & $10.16^{\mathrm{a}}$ & & $0.107^{\mathrm{a}}$ & $40.968^{\mathrm{a}}$ & & $-413.753^{b}$ & & & 0.24 \\
\hline SK & $-0.12^{\mathrm{a}}$ & $5.59^{a}$ & & & $-8.78^{a}$ & $-610.61^{a}$ & $-175.83^{a}$ & $-428.06^{a}$ & 0.31 \\
\hline SI & $0.05^{\mathrm{a}}$ & $-13.17^{b}$ & & $-21.37^{\mathrm{a}}$ & $62.76^{\mathrm{a}}$ & & $256.11^{\mathrm{a}}$ & & 0.44 \\
\hline BG & $0.19^{a}$ & & $0.01^{\mathrm{a}}$ & & $-2.02^{\mathrm{a}}$ & $-18.14^{\mathrm{a}}$ & & $-69.54^{b}$ & 0.71 \\
\hline RO & $0.03^{\mathrm{a}}$ & & & & & $161.66^{\mathrm{a}}$ & $-91.89^{a}$ & & 0.13 \\
\hline DE & $-0.17^{\mathrm{a}}$ & $-43.25^{a}$ & $-0.003^{\mathrm{a}}$ & $12.02^{\mathrm{a}}$ & $-0.06^{\mathrm{a}}$ & & & $-368.92^{c}$ & 0.10 \\
\hline FR & $0.001^{\mathrm{a}}$ & $-7.62^{\mathrm{a}}$ & & $-14.51^{c}$ & $-34.29^{b}$ & & $-61.48^{\mathrm{a}}$ & & 0.24 \\
\hline
\end{tabular}

Source: author's calculations based on data from Orbis databases Symbols ${ }^{a}$, ${ }^{b}$ or $^{c}$ indicate significance at $1 \%, 5 \%$, or $10 \%$.

The Table 6 presents the results of large manufacturing companies. They are as diverse as they do or do not meet our expectations as it is in case of medium-sized companies. Expectations were set for medium-sized companies as well and were also discussed with regard to the economic developments in the countries. The explanations are often the same. There were Austria and Hungary added to the Table 6. It is therefore appropriate to analyze their results, too.

The companies showed a positive relation between the overall debt and profitability, which means that the companies were more in debt as profits grew. They looked more credible due to higher profitability though so creditors were willing to provide them with loans. The growth is also supported by a positive relation with the total and long-term debt considering the speed of GDP growth. Although the Austrian economy had some minor problems due to the financial crisis, the economy grew by $2 \%$ per year on average with one exception in 2013. Growth in debt is also connected to a positive relation with interest rates as it comes to total and long-term debt. As mentioned above, interest rates in the Euro zone were of very low level, which supported debt financing. As all types of debt are considered, a negative relation with inflation is expected, as the average inflation rate was $2 \%$ over the given period, so it was impossible to use the "cheaper debt". In case of total indebtedness, the positive relation with the non-debt tax shield is special, because, as with medium-sized companies, probably, it has to be explained by different tax laws. Here, too, the value of tangible assets does not approach the value of depreciation.

The other economy concerned; Hungary is. It only provided with results of short-term debt. In terms of the negative relation between debt and profitability, debt decreased from a debt-equity ratio from $127 \%$ to $30 \%$ in 2011 and profits increased throughout the researched period. The decline in debt occurred due to the appreciation of the forint against the Swiss franc at the end of 2011. The positive impact of the non-debt tax shield can again be explained by different tax legislation. The last result, the positive relation with the GDP growth rate is, although the impact is opposite than expected. It can be explained by very good growth in the middle of the examined period (around 4-5\%); such growth created optimism even in the short-term period and companies could thus become more indebted.

TABLE 6. GMM results for large manufacturing companies

\begin{tabular}{|c|c|c|c|c|c|c|c|c|c|}
\hline & DER(-1) & ROA & L2 & SA & DEPR & GDP & INF & IR & $J$-stat \\
\hline \multicolumn{10}{|c|}{ Large companiess } \\
\hline \multicolumn{10}{|c|}{ Total debt } \\
\hline AT & $0.02^{\mathrm{a}}$ & $8.95^{a}$ & & $2.39^{\mathrm{a}}$ & $17.15^{b}$ & $13.29^{\mathrm{a}}$ & $-48.27^{a}$ & $142.71^{\mathrm{a}}$ & 0.42 \\
\hline SI & $-0.22^{\mathrm{a}}$ & $-14.48^{\mathrm{a}}$ & & $2.21^{\mathrm{a}}$ & $9.17^{\mathrm{a}}$ & $8.08^{\mathrm{a}}$ & & $82.91^{\mathrm{a}}$ & 0.21 \\
\hline BG & $-0.01^{\mathrm{a}}$ & & $0.67^{\mathrm{a}}$ & & $-60.58^{a}$ & & $-27.84^{a}$ & & 0.25 \\
\hline Ro & $-0.03^{\mathrm{a}}$ & & $0.82^{\mathrm{a}}$ & & & $-521.91^{a}$ & $251.68^{\mathrm{a}}$ & & 0.18 \\
\hline DE & $0.54^{\mathrm{a}}$ & $16.63^{\mathrm{a}}$ & & $37.49^{\mathrm{a}}$ & $194.10^{\mathrm{a}}$ & $-91.10^{a}$ & & $651.40^{\mathrm{a}}$ & 0.09 \\
\hline IT & $0.03^{\mathrm{a}}$ & & $-0.11^{\mathrm{a}}$ & $5.43^{\mathrm{b}}$ & & & & $734.81^{\mathrm{a}}$ & 0.35 \\
\hline FR & $0.01^{\mathrm{a}}$ & $-2.74^{c}$ & & & & $528.33^{\mathrm{a}}$ & $69.93^{\mathrm{c}}$ & & 0.14 \\
\hline
\end{tabular}

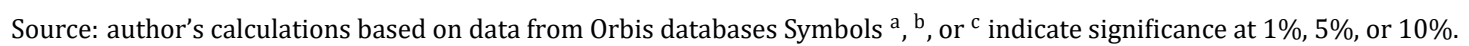


TABLE 6. Continue...

\begin{tabular}{|c|c|c|c|c|c|c|c|c|c|}
\hline & DER(-1) & ROA & L2 & SA & DEPR & GDP & INF & IR & $J$-stat \\
\hline \multicolumn{10}{|c|}{ Long-term debt } \\
\hline SK & $0.17^{\mathrm{a}}$ & $-0.35^{\mathrm{a}}$ & $-0.15^{\mathrm{a}}$ & & $-1.06^{\mathrm{a}}$ & & $-5.35^{\mathrm{a}}$ & $26.66^{\mathrm{a}}$ & 0.09 \\
\hline AT & $0.03^{\mathrm{a}}$ & & & $17.06^{\mathrm{a}}$ & & $6.33^{\mathrm{a}}$ & $-50.22^{\mathrm{a}}$ & & 0.48 \\
\hline $\mathrm{BG}$ & $0.27^{\mathrm{a}}$ & $-2.16^{\mathrm{a}}$ & & $0.76^{\mathrm{a}}$ & $10.33^{\mathrm{a}}$ & & $-3.22^{\mathrm{a}}$ & & 0.24 \\
\hline RO & $-0.23^{\mathrm{a}}$ & & & $3.56^{\mathrm{a}}$ & & $-19.81^{a}$ & & $-40.61^{a}$ & 0.07 \\
\hline $\mathrm{DE}$ & $0.10^{\mathrm{a}}$ & & & $18.12^{\mathrm{a}}$ & $26.08^{\mathrm{a}}$ & & $-141.96^{a}$ & $226.77^{\mathrm{a}}$ & 0.19 \\
\hline FR & $-0.09^{\mathrm{a}}$ & $-43.45^{a}$ & & $-16.72^{a}$ & & $113.55^{\mathrm{a}}$ & & & 0.11 \\
\hline \multicolumn{10}{|c|}{ Short-term debt } \\
\hline PL & $0.18 \mathrm{a}$ & $-47.11 a$ & & $13.80^{\mathrm{a}}$ & $-221.96^{a}$ & & $-72.61^{a}$ & $138.96^{\mathrm{a}}$ & 0.08 \\
\hline HU & $0.01^{\mathrm{a}}$ & $-10.61^{a}$ & $-0.27^{\mathrm{a}}$ & & $21.19^{\mathrm{a}}$ & $15.54^{\mathrm{a}}$ & & & 0.25 \\
\hline AT & $-0.44^{\mathrm{a}}$ & & & $-0.28^{\mathrm{b}}$ & $-3.41^{\mathrm{a}}$ & & $-5.73^{\mathrm{a}}$ & & 0.64 \\
\hline SI & $-0.19^{a}$ & $-11.64^{a}$ & $0.66^{\mathrm{a}}$ & & & $-1.98^{\mathrm{a}}$ & $83.25^{\mathrm{a}}$ & & 0.24 \\
\hline BG & $-0.03^{\mathrm{a}}$ & & & $-13.63^{a}$ & & $43.53^{\mathrm{a}}$ & & $1017.64^{b}$ & 0.34 \\
\hline RO & $-0.01^{b}$ & & $-0.41^{\mathrm{a}}$ & $-25.09^{c}$ & $-81.47^{\mathrm{a}}$ & & $268.30^{\mathrm{a}}$ & $-650.23^{\mathrm{a}}$ & 0.09 \\
\hline DE & $0.38^{\mathrm{a}}$ & $15.57^{\mathrm{a}}$ & & & $165.42^{\mathrm{a}}$ & & & & 0.25 \\
\hline IT & $0.01^{\mathrm{a}}$ & & $-0.07^{b}$ & & $-52.55^{\mathrm{a}}$ & $-33.29^{a}$ & & $654.94^{\mathrm{a}}$ & 0.20 \\
\hline
\end{tabular}

Source: author's calculations based on data from Orbis databases Symbols ${ }^{\mathrm{a}},{ }^{\mathrm{b}}$, or ${ }^{\mathrm{c}}$ indicate significance at $1 \%, 5 \%$, or $10 \%$.

If we compare manufacturing companies by size, there is no big difference between them. Companies are affected by both internal and external factors. However, the highest coefficient values were determinants of the external environment of companies. Interest rates have the greatest impact and therefore, manufacturing companies of all sizes should focus primarily on the external environment and should learn to work with GDP growth rate, inflation rate and interest rates to optimize their financial structure.

Given that the expected impacts of the individual determinants have been recalled in the results of manufacturing companies, the results of sellers being analyzed show that more or less, they are not in accordance with the assumptions. Table 7 shows the resulting coefficients for medium wholesale and retail companies.

In terms of profitability, the results are about half and half. Slovak and Polish companies show positive relation between total debts and debts, Slovak companies show positive relation between long-term debt and debt, Polish and Hungarian companies show positive relation between short-term debt and debt; all those companies did not meet the prediction expressed in the beginning of this paper. In case of Hungary and Poland, relation between debt and total debt is in accordance with the coefficient of GDP growth speed. Companies are more indebted as the economy thrives and profits grow. This is not surprising as it comes to the Polish economy as it was one of the few that was not affected by the financial crisis or any other crisis, it did not go through the economic recession. In case of Hungary, the effects of the crisis were severe but the econ- omy recovered relatively quickly thanks to the IMF loan and governmental reforms. It has been growing very fast since 2013, which probably surpassed the effects of the crisis that still persisted in the first half of the period.

In terms of asset structure, only two economies did not meet our expectations, Hungary in long-term debt and Austria in short-term debt. Austrian companies dispose of $85 \%$ tangible assets of total assets; it seems to have a different approach to collateral of short-term external funds. However, the coefficient is very low and can be taken as a deviation. There is a much larger coefficient for Hungarian companies. The explanation is difficult as companies handle on average $92 \%$ of tangible assets of total assets and should rather show the positive impact on the level of debt.

Again, the positive effects of the non-debt tax shield in Slovak, Romanian, Italian and Austrian companies can only be explained by probable differences in tax laws, as in this case too, the value of tangible assets is not close to the value of depreciation.

As for the impact of GDP, the assumptions were not met by the German and Italian companies as it comes to overall debt, the German, Polish, Hungarian and French companies as for long-term debt and the Hungarian and Slovak companies as for short-term debt. The German economy grew at a steady pace within almost entire period and as a result, companies used increasing profits and parts thereof (e.g., retained earnings) to finance their activities. This fact can also be illustrated by the negative impact of profitability on total debt. The same explanation can be applied to France, Poland and Hungary in the context of long-term debt. Italy's 
GDP declined in 2012 and 2013 and growth was not high in subsequent years. On average, the GDP growth rate is zero over the entire considered period. Italy belongs to the countries that have been hit by the financial crisis, the European debt crisis or other banking crises.

The positive impact of inflation in Bulgarian, Italian and German companies is unusual, as the average inflation rate over the whole researched period was $1 \%$ and therefore, a cheaper debt is disadvantageous whether existing or newly incurred one.

The last variable discussed; the interest rate is. As for this part, most countries did not fulfill the assumptions. In case of Bulgarian economy, there is a very high negative coefficient, which can be explained by the fact that if the economy is doing well, and Bulgarian does, companies have no serious reason to indebt themselves more neither during decline. Companies used rather their own resources, existence of which is proved by negative impact of profitability on debt. A similar explanation can be applied to Austria and Germany and their negative coefficients. As for the explanation of the positive impact of interest rate on debt in the Hungarian economy, the economy was relatively prosperous, interest rates fell and companies took advantage of this fact and increased their debt. Poland is the last economy showing a positive impact of interest rate on the level of debt. Companies have become more indebted as a result of economic prosperity and falling interest rates. The European football championship during the given period could also help.

In case of large wholesale and retail companies, there are far more impacts in Table 8 not meeting entry expectations. Profitability is not met by Czech, Slovak and Romanian companies as for total debt; by Czech, Slovak and German companies as for long-term debt; and by Czech, Romanian and German companies as for short-term debt. The reason, as it comes to Czech, Slovak and German companies, may be the relation with the business cycle, which would be indicated by positive coefficients of the rate of GDP growth. All these economies were more or less prosperous during the period and therefore, companies could be more indebted as their profits grew and they looked credible in the eyes of creditors.

TABLE 7. GMM results for medium-sized wholesale and retail companies

\begin{tabular}{|c|c|c|c|c|c|c|c|c|c|}
\hline & DER(-1) & ROA & $\mathbf{L 2}$ & SA & DEPR & GDP & INF & IR & $J$-stat \\
\hline \multicolumn{10}{|c|}{ Medium-sized companies } \\
\hline \multicolumn{10}{|c|}{ Total debt } \\
\hline SK & $-0.03^{\mathrm{a}}$ & $6.68^{\mathrm{c}}$ & & & $23.16^{\mathrm{c}}$ & & $-124.38^{\mathrm{a}}$ & $489.73^{c}$ & 0.10 \\
\hline PL & $-0.05^{a}$ & $5.87^{\mathrm{c}}$ & & $2.95^{\mathrm{a}}$ & & $97.98^{\mathrm{a}}$ & & & 0.66 \\
\hline HU & $-0.02^{\mathrm{a}}$ & & $0.09^{\mathrm{a}}$ & & $-3.55^{\mathrm{c}}$ & & $-38.87^{c}$ & $44.61^{\mathrm{a}}$ & 0.11 \\
\hline AT & $-0.08^{a}$ & & & $17.83^{\mathrm{a}}$ & & $87.64^{b}$ & $-65.38^{c}$ & $242.72^{\mathrm{a}}$ & 0.13 \\
\hline BG & $0.92^{\mathrm{a}}$ & $-5.04^{\mathrm{a}}$ & & & & & $62.37^{c}$ & $-1181.73^{c}$ & 0.61 \\
\hline RO & & $-12.40^{c}$ & $0.03^{\mathrm{a}}$ & $133.66^{\mathrm{a}}$ & $160.07^{a}$ & & & & 0.14 \\
\hline $\mathrm{DE}$ & & $-15.59^{a}$ & & & $-79.43^{a}$ & $-80.36^{c}$ & & $-734.30^{\mathrm{a}}$ & 0.80 \\
\hline IT & $-0.01^{\mathrm{a}}$ & & $0.15^{\mathrm{a}}$ & $3.52^{\mathrm{b}}$ & & $-131.77^{a}$ & $378.11^{c}$ & & 0.08 \\
\hline FR & $-0.003^{\mathrm{a}}$ & $-15.23^{\mathrm{a}}$ & & & $-45.15^{c}$ & & & $99.47^{a}$ & 0.18 \\
\hline \multicolumn{10}{|c|}{ Long-term debt } \\
\hline SK & $-0.37 a$ & $12.67^{\mathrm{a}}$ & & & $44.56^{\mathrm{a}}$ & & & & 0.17 \\
\hline PL & $-0.30^{\mathrm{a}}$ & & & & & $-4.64^{c}$ & & $4.55^{c}$ & 0.13 \\
\hline $\mathrm{HU}$ & $-0.03^{a}$ & & $0.62^{\mathrm{a}}$ & $-2.45^{c}$ & & $-22.11^{\mathrm{a}}$ & $-65.66^{a}$ & $34.47^{\mathrm{a}}$ & 0.32 \\
\hline AT & $-0.08^{a}$ & & & $17.80^{\mathrm{a}}$ & & $100.71^{b}$ & $-61.45^{c}$ & $273.00^{\mathrm{a}}$ & 0.29 \\
\hline SI & $0.01^{\mathrm{a}}$ & $-0.34^{c}$ & & $1.54^{\mathrm{a}}$ & & & & & 0.23 \\
\hline RO & $0.004^{\mathrm{a}}$ & $-2.45^{b}$ & $0.01^{\mathrm{a}}$ & & $3.33^{c}$ & & & $-209.61^{a}$ & 0.12 \\
\hline $\mathrm{DE}$ & & & & $9.34^{\mathrm{a}}$ & $-1.39^{c}$ & $-25.20^{\mathrm{b}}$ & $54.99^{\mathrm{b}}$ & & 0.45 \\
\hline FR & $-0.002^{\mathrm{a}}$ & $-6.55^{a}$ & & & & $-11.23^{c}$ & & $67.12^{\mathrm{a}}$ & 0.10 \\
\hline \multicolumn{10}{|c|}{ Short-term debt } \\
\hline $\mathrm{CZ}$ & $-0.23^{\mathrm{a}}$ & $-0.15^{c}$ & $-0.01^{\mathrm{a}}$ & & $-21.28^{a}$ & $-60.45^{a}$ & & & 0.18 \\
\hline SK & $0.01^{\mathrm{a}}$ & & & $-12.43^{a}$ & & $49.68^{c}$ & $-103.49^{c}$ & & 0.09 \\
\hline PL & $-0.03^{a}$ & $3.27^{\mathrm{b}}$ & $0.33^{b}$ & & & & & $51.22^{\mathrm{c}}$ & 0.34 \\
\hline $\mathrm{HU}$ & $0.07^{a}$ & $0.213^{c}$ & & & $-3.68^{b}$ & $25.49^{b}$ & $38.94 \mathrm{~b}$ & & 0.33 \\
\hline AT & $-0.26^{a}$ & & & $0.22^{\mathrm{c}}$ & $8.26^{\mathrm{c}}$ & $-2.63^{\mathrm{a}}$ & $13.65 a$ & $-21.50^{\mathrm{a}}$ & 0.10 \\
\hline $\mathrm{BG}$ & $0.14^{\mathrm{a}}$ & & $-0.56^{\mathrm{a}}$ & & & & $81.25^{\mathrm{a}}$ & $-1665.77^{c}$ & 0.57 \\
\hline $\mathrm{DE}$ & $-0.05^{a}$ & $-4.91^{\mathrm{a}}$ & & $-4.45^{\mathrm{a}}$ & & $-23.61^{a}$ & & $-261.10^{c}$ & 0.71 \\
\hline IT & $-0.01^{\mathrm{a}}$ & & & $-13.68^{c}$ & $31.46^{\mathrm{a}}$ & & $-98.42^{\mathrm{a}}$ & & 0.12 \\
\hline FR & $-0.004^{\mathrm{a}}$ & $-0.53^{a}$ & & $-3.81^{b}$ & $-36.96^{c}$ & & & $78.51^{\mathrm{c}}$ & 0.06 \\
\hline
\end{tabular}

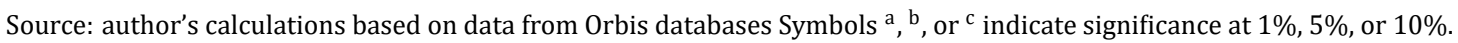


The expected relation between the asset structure and the debt level is not met by the Slovak, Bulgarian, German and French companies as for total debt, the French companies as for long-term debt and the Austrian companies as for shortterm debt. As it comes to Bulgarian and French companies, this unusualness is shown due to a detailed composition of assets; intangible assets predominate in France (77\%) or tangible assets become almost even with intangible ones in Bulgaria (45\%). These assets cannot be used as collateral and therefore the companies' indebtedness cannot increase much. However, in Slovakia and Germany, tangible assets predominate in the assets composition and this relation is therefore difficult to explain.

The non-debt tax shield shows a positive impact on debt in Romanian companies as for total debt, in Italian companies as for long-term debt, and in Bulgarian, Romanian and German companies as for short-term debt. As in all previous cases, unfortunately, the value of tangible assets in these companies is not close to the value of depreciation and the difference in the expected impact can be caused by different tax legislations.

Only one economy did not meet the assumed results as it comes to impact of debt on the GDP growth rate-Austria, in all forms of debt. Unfortunately, the explanation of the negative relation between total and long-term debt cannot be derived from the profitability coefficient. Nevertheless, it can be said that companies had enough own resources to finance investment activities as interest rates declined during 2010-2018, which was another impulse to rather get into debt, but here the coefficient is also negative. Sufficient financial resources can be derived from the GDP growth rate, which was $2 \%$ on average.

Germany, the Czech Republic, Italy, Romania and Bulgaria did not meet inflation expectations. In all economies except Romania, the inflation rate was relatively low of around 1-2\%; there was no reason for higher debt because the cheaper debt was no advantage. Romania had an average inflation rate of $3 \%$, and even of $6 \%$ over some years, and hence higher inflation could bring greater benefits and debt growth.

Hungary and Austria did not meet the prerequisites for interest rates. The possible reason as it comes to the Austrian unusualness was explained above. As far as Hungary is concerned, this economy has been relatively successful with interest rates falling during the said period, which prompted companies to make greater use of external financing. If we compare wholesale and retail companies by size, there is no big difference between them. Companies are affected by both internal and external factors. However, the highest coefficient values were among the determinants of the companies' external environment. Interest rates have the greatest impact and therefore wholesale and retail companies of all sizes should focus primarily on the external environment and should learn to work with GDP growth rates, inflation rates and interest rates to optimize their financial structure. Nevertheless, depreciation had the same weight as the GDP growth rate so it would be appropriate to focus on this determinant.

TABLE 8. GMM results for large wholesale and retail companies

\begin{tabular}{|c|c|c|c|c|c|c|c|c|c|}
\hline & DER(-1) & ROA & $\mathbf{L 2}$ & SA & DEPR & GDP & INF & IR & $J$-stat \\
\hline \multicolumn{10}{|c|}{ Large companies } \\
\hline \multicolumn{10}{|c|}{ Total debt } \\
\hline $\mathrm{CZ}$ & $0.004 a$ & $8.99^{b}$ & & & & $59.24^{\mathrm{b}}$ & $-151.39^{a}$ & $515.60^{\mathrm{a}}$ & 0.24 \\
\hline SK & $-0.47^{\mathrm{a}}$ & $31.25^{\mathrm{a}}$ & & $-13.37^{b}$ & $-57.59^{a}$ & & & $684.27^{b}$ & 0.39 \\
\hline HU & $0.01^{\mathrm{a}}$ & & $-0.02^{\mathrm{a}}$ & & $-65.53^{a}$ & $37.69^{\mathrm{a}}$ & & $39.02^{b}$ & 0.52 \\
\hline AT & $0.35^{\mathrm{a}}$ & & & $20.46^{\mathrm{a}}$ & $-90.14^{\mathrm{a}}$ & $-29.17^{\mathrm{a}}$ & $-130.20^{\mathrm{a}}$ & & 0.10 \\
\hline $\mathrm{BG}$ & $-0.04^{\mathrm{a}}$ & $-39.35^{a}$ & & $-183.31^{a}$ & & & & & 0.28 \\
\hline RO & $0.12 \mathrm{a}$ & $48.08 a$ & $0.17 \mathrm{a}$ & & $61.44 \mathrm{a}$ & & $291.49^{\mathrm{a}}$ & $-309.74^{\mathrm{a}}$ & 0.15 \\
\hline $\mathrm{DE}$ & & & & $-49.71^{b}$ & & $333.25^{c}$ & $291.87^{b}$ & & 0.36 \\
\hline IT & $0.01^{\mathrm{a}}$ & $-15.03^{c}$ & $-0.07^{\mathrm{a}}$ & & & $84.59^{a}$ & & $121.07^{\mathrm{a}}$ & 0.06 \\
\hline FR & $-0.001^{\mathrm{a}}$ & & & $-91.40^{c}$ & & $945.07^{\mathrm{a}}$ & $-2165.12^{\mathrm{a}}$ & $1305.77^{\mathrm{a}}$ & 0.82 \\
\hline \multicolumn{10}{|c|}{ Long-term debt } \\
\hline $\mathrm{CZ}$ & $0.10^{\mathrm{a}}$ & $1.21^{\mathrm{b}}$ & & $9.27^{\mathrm{a}}$ & & & $-2.61^{b}$ & & 0.14 \\
\hline SK & $-0.23^{\mathrm{a}}$ & $3.30^{\mathrm{a}}$ & & & & $21.32^{\mathrm{a}}$ & $-4.82^{\mathrm{a}}$ & $83.72^{\mathrm{a}}$ & 0.42 \\
\hline AT & $0.34^{\mathrm{a}}$ & & & $9.35^{\mathrm{a}}$ & $-49.90^{a}$ & $-65.80^{a}$ & & $-520.27^{\mathrm{a}}$ & 0.09 \\
\hline SI & $0.24^{\mathrm{a}}$ & & $-0.08^{\mathrm{a}}$ & $13.14^{\mathrm{a}}$ & $-38.73^{a}$ & $11.94^{\mathrm{a}}$ & $3.17 \mathrm{a}$ & & 0.10 \\
\hline
\end{tabular}

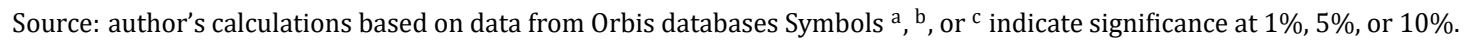


TABLE 8. Continue...

\begin{tabular}{|c|c|c|c|c|c|c|c|c|c|}
\hline & $\operatorname{DER}(-1)$ & ROA & L2 & SA & DEPR & GDP & INF & IR & $J$-stat \\
\hline RO & $-0.04^{\mathrm{a}}$ & & $0.07^{\mathrm{a}}$ & $5.75^{\mathrm{a}}$ & & $63.34^{\mathrm{a}}$ & & & 0.26 \\
\hline $\mathrm{DE}$ & $0.002^{\mathrm{b}}$ & $6.33^{\mathrm{a}}$ & & & & $392.73^{c}$ & & $1118.42^{b}$ & 0.12 \\
\hline IT & & & $-0.11^{a}$ & & $21.40^{\mathrm{b}}$ & & $-18.56^{a}$ & $32.59^{\mathrm{a}}$ & 0.16 \\
\hline FR & $0.002^{\mathrm{c}}$ & $-7.83^{\mathrm{a}}$ & & $-16.84^{a}$ & $-38.09^{c}$ & & $-184.12^{\mathrm{b}}$ & $168.39^{b}$ & 0.06 \\
\hline \multicolumn{10}{|c|}{ Short-term debt } \\
\hline $\mathrm{CZ}$ & $0.004 \mathrm{a}$ & $7.50 \mathrm{~b}$ & & & & $63.27^{\mathrm{b}}$ & $-138.73^{a}$ & $530.65^{\mathrm{a}}$ & 0.19 \\
\hline PL & $0.04^{\mathrm{a}}$ & $-0.78^{c}$ & & $-2.06^{\mathrm{b}}$ & & & $240.48^{\mathrm{a}}$ & & 0.08 \\
\hline $\mathrm{HU}$ & $-0.03^{\mathrm{a}}$ & & $-0.02^{\mathrm{a}}$ & & $-49.66^{b}$ & & $15.33^{c}$ & $39.15^{\mathrm{a}}$ & 0.53 \\
\hline AT & $0.11^{\mathrm{a}}$ & & & $4.21^{b}$ & & $21.40^{\mathrm{a}}$ & & $-38.95^{\mathrm{a}}$ & 0.29 \\
\hline BG & $-0.04^{\mathrm{a}}$ & $-39.71^{a}$ & $1.18^{\mathrm{b}}$ & $-198.73^{a}$ & $593.57^{\mathrm{a}}$ & & $164.02^{\mathrm{a}}$ & & 0.26 \\
\hline Ro & $0.10^{\mathrm{a}}$ & $36.96^{\mathrm{a}}$ & & & $41.32^{\mathrm{a}}$ & $-32.12^{b}$ & $159.67^{\mathrm{a}}$ & & 0.19 \\
\hline $\mathrm{DE}$ & $0.01^{\mathrm{b}}$ & $9.74^{\mathrm{a}}$ & & $-9.26^{b}$ & $24.66^{\mathrm{b}}$ & & & & 0.43 \\
\hline IT & $0.01^{\mathrm{a}}$ & $-11.85^{c}$ & $-0.07^{\mathrm{a}}$ & & & $-23.99^{c}$ & $-77.50^{b}$ & $224.52^{\mathrm{a}}$ & 0.14 \\
\hline
\end{tabular}

Source: author's calculations based on data from Orbis databases Symbols ${ }^{a}$, ${ }^{b}$ or $^{c}$ indicate significance at $1 \%, 5 \%$, or $10 \%$.

\section{CONCLUSION AND IMPLICATIONS}

This research dealt with the financial structure and its selected determinants. The subject of the research, the automotive industry of two areas was-manufacturing and sale of motor vehicles. The sectors were analysed in these 11 economies-the Visegrád Group countries, Bulgaria, Romania, Austria, Slovenia, Germany, Italy, and France. Selected CEE countries and European leading companies in this sector were compared. Determinants were determined - profitability, liquidity, asset structure, non-debt tax shield, macroeconomic development, inflation and basic interest rates. The financial structure was characterized by three forms of debt - short-term, long-term and total. In total, the five research questions were considered at 54,927 medium, large and very large companies; the period involved in the research was from 2010 to 2018.

Panel regression using the GMM model was used to assess the impact of determinants. The aim of this research was to determine the influence of selected factors on the companies' financial structure of eleven selected economies belonging to manufacturing and wholesale and retail trade of motor vehicles.

As it comes to comparison of the sectors using the individual determinants, regardless of the sector, the liquidity ratios were very low. Therefore, for any sectors, no effect of liquidity on the level of indebtedness of the companies concerned can be clearly confirmed. The only thing that the results suggest is that in both sectors, positive impacts prevail in medium-sized companies while in large companies, negative ones predominate.

In case of profitability seen from the point of economies view, the resulting relations are about half and half with a slight predominance of negative ones, which means that if profits increase companies used own financing sources (e.g., retained earnings) to finance their investment activities. Far more important, the size of the coefficients is meaning the strength of binding and influence. Mediumsized manufacturing companies have high coefficients compared to sellers, which means that the profitability of these companies has a much greater impact on the debt level. As for large companies, it is exactly the opposite situation at the first sight. The impact of profitability on the debt amount is higher for sellers than for producers.

The assets structure in case of medium-sized enterprises has both positive and negative impacts. If we look at the level of the coefficients and thus the strength of impact, then medium-sized enterprises, regardless of the sector, have a greater positive impact, while for large enterprises, they have a greater negative impact. However, in both cases, sellers reported higher values, which look strange as tangible assets are more or less represented by sales of buildings, while producers have also production machines in these assets included, etc. Thus, it could be assumed that manufacturing companies should have a larger quantity of them.

The non-debt tax shield was the last in-company determinant. Considering this factor, the selected companies vary greatly. Although the predominance of the negative impact on the debt level applies to both sectors, the predominance of the manufacturing sector is more significant in terms of the number of coefficients. Nevertheless, the strength of the impact is higher for positive impacts due to higher coefficients. For retailers, the impact is twice as strong as for manufacturers.

Both sectors analysed are cyclical and therefore, their performance should always depend primarily on the external environment. An important finding of the whole research 
is the fact that this idea was confirmed by the results. It was revealed that in both sectors, companies (even without size difference) are mainly influenced by environmental determinants, represented here by the GDP growth rate, the inflation rate and the basic interest rate. In both sectors, interest rates, followed by GDP and inflation rates, had the greatest impact on the financial structure and thus the level of corporate debt. This implies that companies in these sectors should focus primarily on the development of external conditions and should learn how to work with them (e.g., to observe the statements of economists and politicians, to monitor macroeconomic forecasts, etc.) in order to opti- mize their financial structure.

The research was worked on over a nine-year period, but even in today's situation, when the world is affected by the covid-19 pandemic, it can be seen how strongly the automotive industry is hit by this external situation. In many countries, this industry was the first to be closed down and was associated with a large future potential redundancy.

\section{ACKNOWLEDGMENT}

This article was supported by SGS/16/2020 Influence of selected internal and macroeconomic determinants on financial structure of companies in selected countries of Central and Eastern Europe.

\section{REFERENCES}

Acedo Ramirez, M. A., \& Ruiz Cabestre, F. J. (2014). Determinants of capital structure: United Kingdom versus continental European countries. Journal of International Financial Management \& Accounting, 25(3), 237-270. doi:https://doi .org/10.1111/jifm.12020

Akdal, S. (2011). How do firm characteristics affect capital structure? Some UK evidence (Unpublished master's thesis). Krannert School of Management, Purdue University, West Lafayette, Indiana.

Antoniou, A., Guney, Y., \& Paudyal, K. (2002). The determinants of corporate capital structure: Evidence from European countries (Technical report). Centre for Empirical Research in Finance, Department of Economics and Finance, University of Durham, Durham, England.

Arellano, M., \& Bond, S. (1991). Some tests of specification for panel data: Monte carlo evidence and an application to employment equations. The Review of Economic Studies, 58(2), 277-297. doi:https://doi.org/10.2307/2297968

Aulova, R., \& Hlavsa, T. (2013). Capital structure of agricultural businesses and its determinants. Agris On-Line Papers in Economics \& Informatics, 5(2), 1-14.

Bastos, D. D., Nakamura, W. T., \& Basso, L. F. C. (2009). Determinants of capital structure of publicly-traded companies in latin america: The role of institutional and macroeconomic factors. Journal of International Finance and Economics, 9(3), 24-39. doi:https://doi.org/10.2139/ssrn.1365987

Bokpin, G. A. (2009). Macroeconomic development and capital structure decision of firms: Evidence from emerging market economies. Studies in Economics and Finance, 26(2), 129-142. doi:https://doi.org/10.1108/10867370910963055

Brealey, R., Myers, S., \& Allen, F. (2011). Principles of corporate finance. New York, NY: McGraw-Hill.

Camara, O. (2012). Capital structure adjustment speed and macroeconomic conditions: U.S MNCs and DCs. International Research Journal of Finance and Economics, 84(7), 106-120. doi:https://doi.org/10.1016/j.mulfin.2012.10.001

Cekrezi, A. (2013). The determinants of capital structure: Evidence from Albania. Academic Journal of Interdisciplinary Studies, 2(9), 370-376. doi:https://doi.org/10.5901/mjss.2014.v5n13p482

Cheng, S.-R., \& Shiu, C.-Y. (2007). Investor protection and capital structure: International evidence. Journal of Multinational Financial Management, 17(1), 30-44. doi:https://doi.org/10.1016/j.mulfin.2006.03.002

De Haas, R., \& Peeters, M. (2006). The dynamic adjustment towards target capital structures of firms in transition economies. Economics of Transition, 14(1), 133-169. doi:https://doi.org/10.1111/j.1468-0351.2006.00237.x

De Jong, A., Kabir, R., \& Nguyen, T. T. (2008). Capital structure around the world: The roles of firm-and country-specific determinants. Journal of Banking \& Finance, 32(9), 1954-1969. doi:https://doi.org/10.1016/j.jbankfin.2007.12.034

Delcoure, N. (2007). The determinants of capital structure in transitional economies. International Review of Economics \& Finance, 16(3), 400-415. doi:https://doi.org/10.1016/j.iref.2005.03.005

Frieder, L., \& Martell, R. (2006). On capital structure and the liquidity of a firm's stock (Unpublished master's thesis). Krannert School of Management, Purdue University, West Lafayette, ID. 
Gaud, P., Jani, E., Hoesli, M., \& Bender, A. (2005). The capital structure of Swiss companies: An empirical analysis using dynamic panel data. European Financial Management, 11(1), 51-69. doi:https://doi.org/10.1111/j.1354-7798.2005 $.00275 . x$

Handoo, A., \& Sharma, K. (2014). A study on determinants of capital structure in India. IIMB Management Review, 26(3), 170-182. doi:https://doi.org/10.1016/j.iimb.2014.07.009

Hanousek, J., \& Shamshur, A. (2011). A stubborn persistence: Is the stability of leverage ratios determined by the stability of the economy? Journal of Corporate Finance, 17(5), 1360-1376. doi:https://doi.org/10.1016/j.jcorpfin.2011.07.004

Hatzinikolaou, D., Katsimbris, G. M., \& Noulas, A. G. (2002). Inflation uncertainty and capital structure: Evidence from a pooled sample of the Dow-Jones industrial firms. International Review of Economics \& Finance, 11(1), 45-55. doi: https://doi.org/10.1016/S1059-0560(01)00085-5

Hernádi, P. , \& Ormos, M. (2010). Capital structure and its choice in Central and Eastern Europe. Acta Oeconomica, 62(2), 229-263. doi:https://doi.org/10.1556/aoecon.62.2012.2.5

Hernádi, P., \& Ormos, M. (2012). What managers think of capital structure and how they act: Evidence from Central and Eastern Europe. Baltic Journal of Economics, 12(2), 47-71. doi:https://doi.org/10.1080/1406099X.2012.10840517

Jõeveer, K. (2013). Firm, country and macroeconomic determinants of capital structure: Evidence from transition economies. Journal of Comparative Economics, 41(1), 294-308. doi:https://doi.org/10.1016/j.jce.2012.05.001

Khemiri, W., \& Noubbigh, H. (2018). Determinants of capital structure: Evidence from sub-Saharan African firms. The Quarterly Review of Economics and Finance, 70(6), 150-159. doi:https://doi.org/10.1016/j.qref.2018.04.010

Klapper, L. F., Sarria-Allende, V., \& Sulla, V. (2002). Small-and medium-size enterprise financing in Eastern Europe. New York, NY: The World Bank.

Lipson, M. L., \& Mortal, S. (2009). Liquidity and capital structure. Journal of Financial Markets, 12(4), 611-644. doi:https:// doi.org/10.1016/j.finmar.2009.04.002

Lourenco, A. J. D. S. M., \& Oliveira, E. C. (2017). Determinants of debt: Empirical evidence on firms in the district of Santarem in Portugal. Contaduria y Administracion, 62(2), 625-643. doi:https://doi.org/10.1016/j.cya.2016.06.010

Mallisa, M., \& Kusuma, H. (2017). Capital structure determinants and firms' performance: Empirical evidence from Thailand, Indonesia and Malaysia. Polish Journal of Management Studies, 16(1), 154-154.

Mateev, M., Poutziouris, P., \& Ivanov, K. (2013). On the determinants of SME capital structure in Central and Eastern Europe: A dynamic panel analysis. Research in International Business and Finance, 27(1), 28-51. doi:https://doi.org/10.1016/ j.ribaf.2012.05.002

Michaelas, N., Chittenden, F., \& Poutziouris, P. (1999). Financial policy and capital structure choice in UK SMEs: Empirical evidence from company panel data. Small Business Economics, 12(2), 113-130. doi:https://doi.org/10.1023/A: 1008010724051

Mokhova, N., \& Zinecker, M. (2013). The determinants of capital structure: The evidence from the European Union. Acta Universitatis Agriculturae et Silviculturae Mendelianae Brunensis, 61(7), 2533-2546. doi:https://doi.org/10.11118/ actaun201361072533

Myers, S. C. (1984). Capital structure puzzle (Technical report). National Bureau of Economic Research, California, CA.

Myers, S. C. (2001). Capital structure. Journal of Economic Perspectives, 15(2), 81-102. doi:https://doi.org/10.1257/ jep.15.2.81

Myers, S. C., \& Rajan, R. G. (1998). The paradox of liquidity. The Quarterly Journal of Economics, 113(3), 733-771. doi: https://doi.org/10.1162/003355398555739

Nivorozhkin, E. (2005). Financing choices of firms in EU accession countries. Emerging Markets Review, 6(2), 138-169. doi:https://doi.org/10.1016/j.ememar.2004.10.002

OICA. (2020a). Production statistics. Retrieved from https://bit.1y/3kcQGH3

OICA. (2020b). Sales statistics. Retrieved from https://bit.1y/2TkpXN3

Onofrei, M., Tudose, M. B., Durdureanu, C., \& Anton, S. G. (2015). Determinant factors of firm leverage: An empirical analysis at iasi county level. Procedia Economics and Finance, 20(6), 460-466. doi:https://doi.org/10.1016/S2212-5671(15) 00097-0

Öztekin, Ö. (2015). Capital structure decisions around the world: Which factors are reliably important? Journal of Financial and Quantitative Analysis, 50(3), 301-323. doi:https://doi.org/10.1017/S0022109014000660 
Pinkova, P. (2013). Determinants of capital structure: Evidence from the Czech automotive industry. Acta Universitatis Agriculturae Et Silviculturae Mendelianae Brunensis, 60(7), 217-224. doi:https://doi.org/10.11118/ actaun 201260070217

Prucha, I. R. (2014). Instrumental variables/method of moments Eestimation. In Fisher, M. M. \& P. Nijkamp (Ed.), Handbook of regional science. Heidelberg, Germany: Springer.

Rajan, R. G., \& Zingales, L. (1995). What do we know about capital structure? Some evidence from international data. The Journal of Finance, 50(5), 1421-1460. doi:https://doi.org/10.1111/j.1540-6261.1995.tb05184.x

Ruckova, P. (2015a). Vliv likvidity a rentability na vyuziti zdroju financovanive zpracovatelskych podnicich $\mathrm{v}$ zemich $\mathrm{v} 4$. Acta Academica Karviniensia, 15(3), 69-79. doi:https://doi.org/10.25142/aak.2015.032

Ruckova, P. (2015b). Vliv podilu dlouhodobeho majetku a rentability na vyuziti cizich zdroju financovaní firem v odvetvi stavebnictvi v zemich v4. Acta Academica Karviniensia, 15(2), 122-135. doi:https://doi.org/10.25142/aak.2015.023

Ruckova, P. (2017). Hodnoceni vlivu rentability na volbu zdroju financovani v podminkach zemi visegradske ctyrky v oblasti energetiky. Scientific Papers of the University of Pardubice, Series D, 39, 140-150.

Salehi, M., \& Manesh, N. B. (2012). A study of the roles of firm and country on specific determinates in capital structure: Iranian evidence. International Management Review, 8(2), 51-62.

Sett, K., \& Sarkhel, J. (2010). Macroeconomic variables, financial sector development and capital structure of Indian private corporate sector during the period 1981-2007. IUP Journal of Applied Finance, 16(1), 34-60.

Shleifer, A., \& Vishny, R. W. (1992). Liquidation values and debt capacity: A market equilibrium approach. The Journal of Finance, 47(4), 1343-1366. doi:https://doi.org/10.1111/j.1540-6261.1992.tb04661.x

Song, H. S. (2005). Capital structure determinants an empirical study of Swedish companies. Retrieved from https://bit. Iy/ $3 n \times 1 K n 1$

Stulz, R., \& Johnson, H. (1985). An analysis of secured debt. Journal of financial Economics, 14(4), 501-521. doi:https:// doi.org/10.1016/0304-405X(85)90024-8

Titman, S., \& Wessels, R. (1988). The determinants of capital structure choice. The Journal of Finance, 43(1), 1-19. doi: https://doi.org/10.1111/j.1540-6261.1988.tb02585.x

Udomsirikul, P., Jumreornvong, S., \& Jiraporn, P. (2011). Liquidity and capital structure: The case of Thailand. Journal of Multinational Financial Management, 21(2), 106-117. doi:https://doi.org/10.1016/j.mulfin.2010.12.008

Wald, J. K. (1999). How firm characteristics affect capital structure: An international comparison. Journal of Financial Research, 22(2), 161-187. doi:https://doi.org/10.1111/j.1475-6803.1999.tb00721.x

Weill, L. (2004). What determines leverage in transition countries? Czech Journal of Economics and Finance, 54(5), 234-242.

Williamson, O. E. (1988). Corporate governance and corporate finance. Journal of Finance, 43(3), 567-591. doi:https:// doi.org/10.1111/j.1540-6261.1988.tb04592.x

Yinusa, O. G., Alimi, O. Y., \& Ilo, B. M. (2016). Macroeconomic determinants of capital structure of firms: Evidence from Nigeria. Journal of Knowledge Globalization, 9(2), 1-21. 
APPENDIX 1

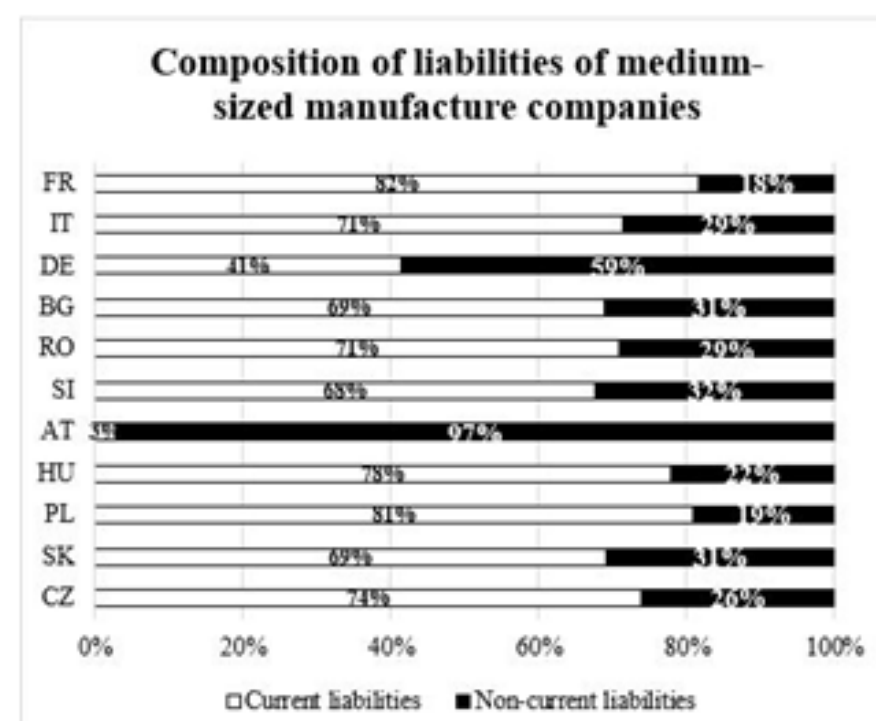

\section{Composition of liabilities of large manufacture companies}

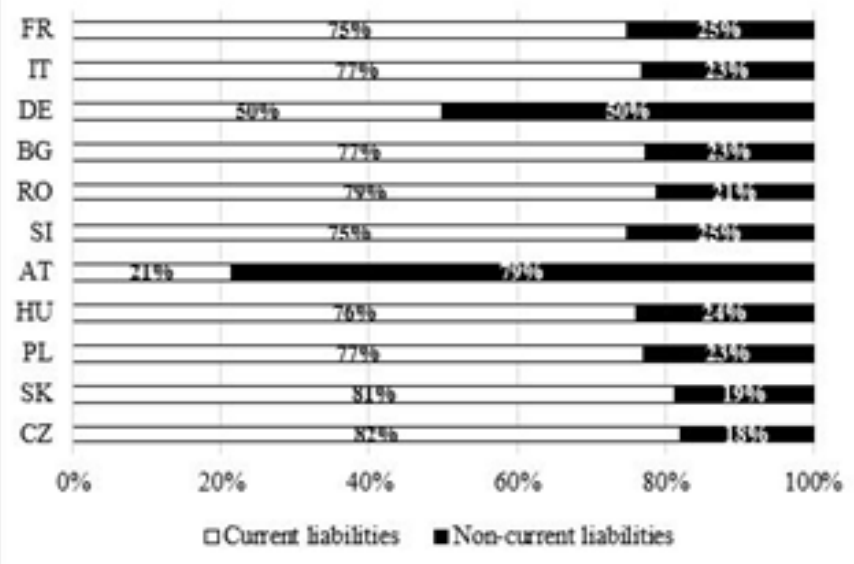

Composition of liabilities of mediumsized wholesale and retail trade companies

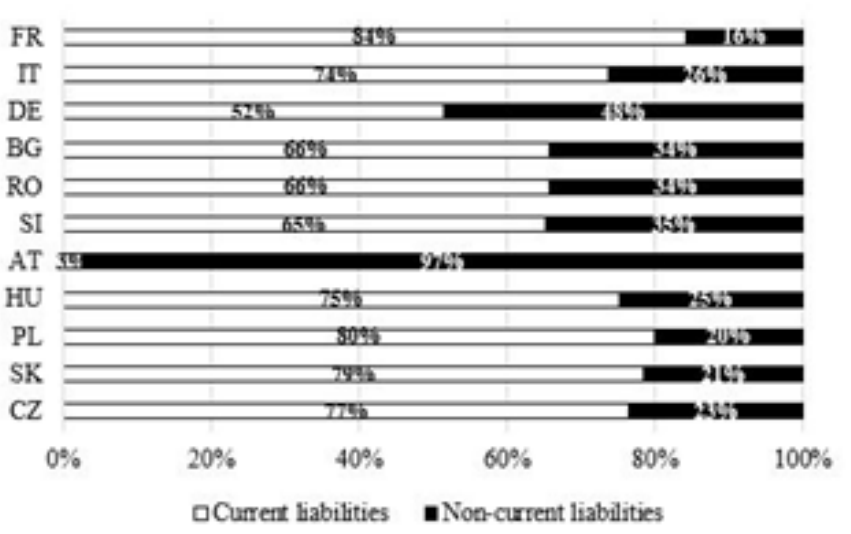

Composition of liabilities of large wholesale and retail trade companies

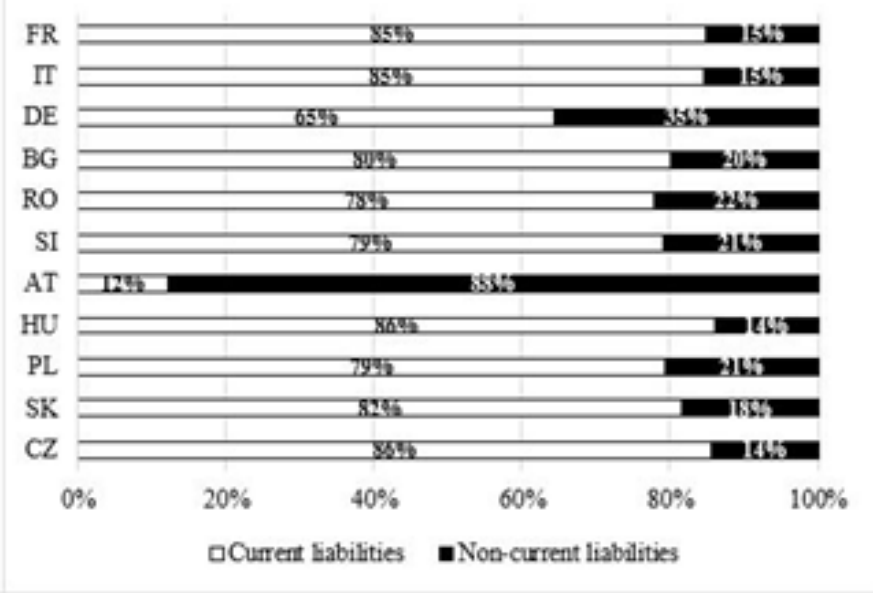


APPENDIX 2

Average share of debt and equity of medium-sized manufacturing companies

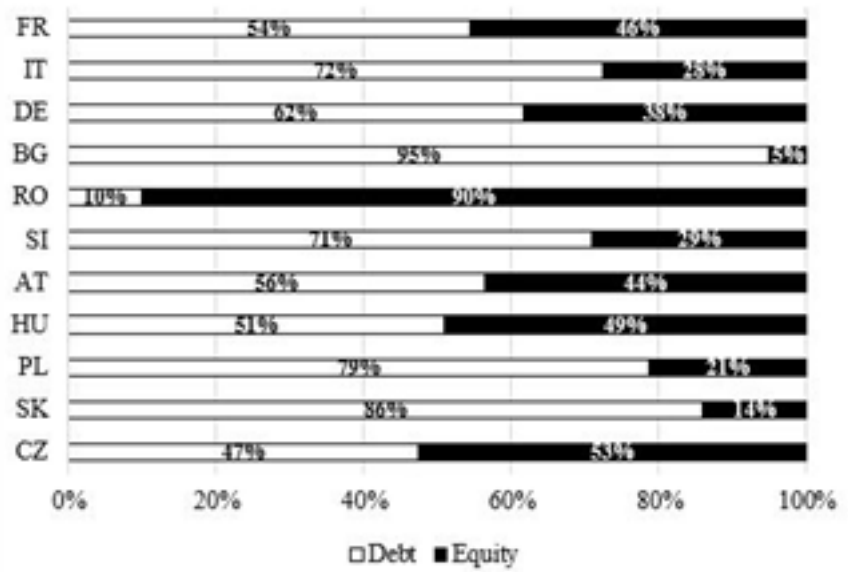

Average share of debt and equity of large manufacturing companies

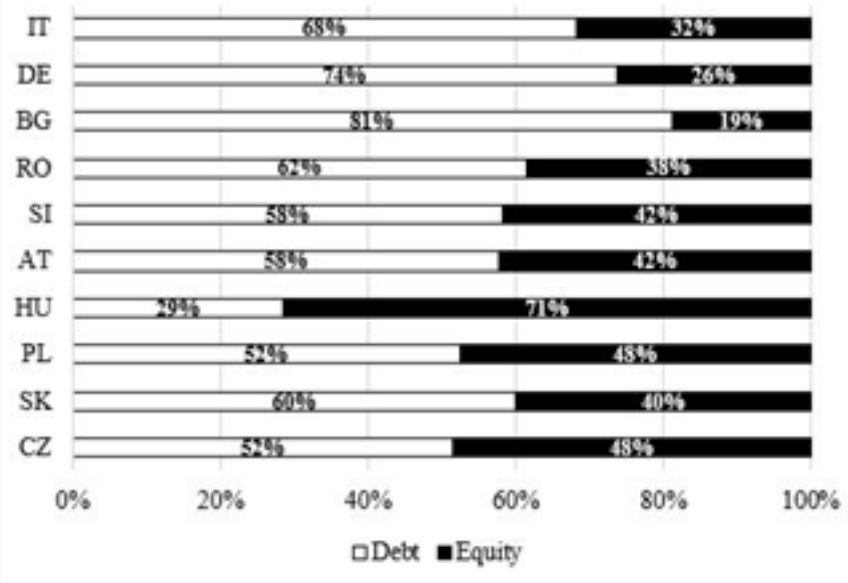

Average share of debt and equity of medium-sized wholesale and retail companies

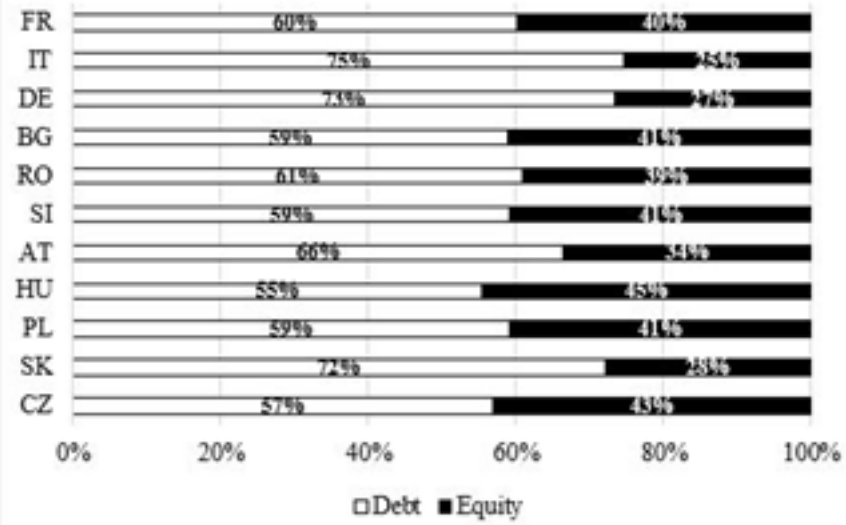

Average share of debt and equity of large wholesale and retail companies

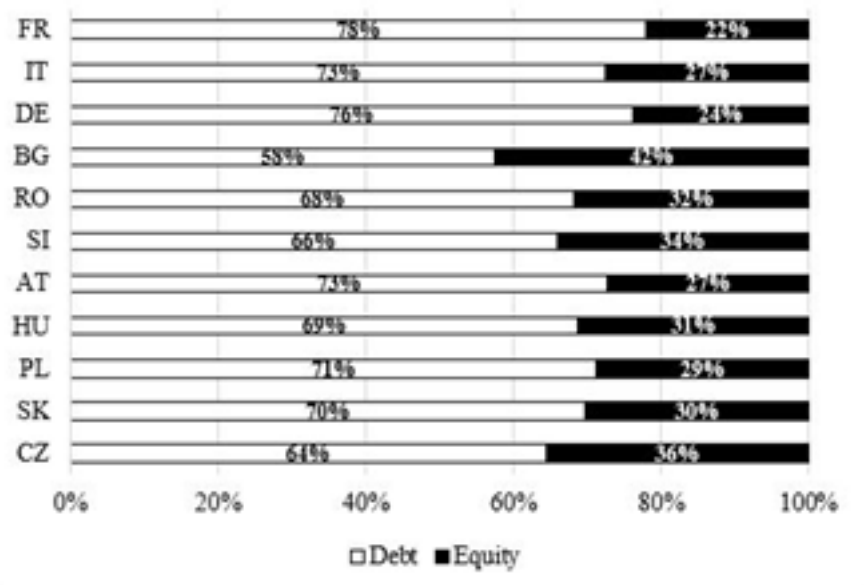

